\title{
PATOLOGIAS NOS SISTEMAS CONSTRUTIVOS DAS EDIFICAÇÕES DO INÍCIO DO SÉCULO XX NO SUL DO RIO GRANDE DO SUL - ESTUDO DE CASO DE RESIDENCIA NA CIDADE DE RIO GRANDE/RS
}

\author{
Pathologies in constructive systems of buildings from the beginning the \\ 20th century in south Rio Grande do Sul - case study of residence in the city of \\ Rio Grande/RS
}

\author{
Ariela da Silva Torres ${ }^{1}$, Juçara Nunes da Silva ${ }^{2}$
}

Recebido em 05 de janeiro de 2015; recebido para revisão em 09 de julho de 2015; aceito em 15 de setembro de 2015; disponível on-line em 22 de setembro de 2015.

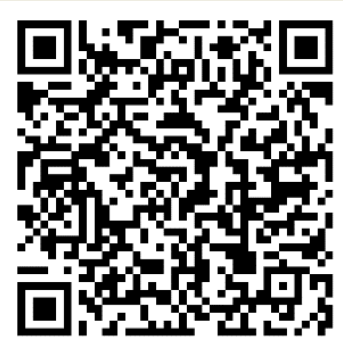

PALAVRAS CHAVE:

Manifestações patológicas em edificações;

Deterioração de Revestimentos;

Ação de capilaridade;

Eflorescência.

\section{KEYWORDS:}

Phatologies in buildings;

Stucco deterioration; Capillary action;

Efflorescence.

\footnotetext{
* Contato com os autores:

${ }^{1}$ e-mail: arielatorres@gmail.com ( A. S. Torres )

Doutora, Professora Departamento de Tecnologia da Construção e Programa de Pós-Graduação em Arquitetura e Urbanismo, Universidade Federal de Pelotas.

2e-mail: arq.jussara@gmail.com ( J. N. Silva )

Arquiteta e Urbanista, Mestranda do Programa Pós-Graduação em Arquitetura e Urbanismo, Universidade Federal de Pelotas
}

RESUMO: Situada na região sul do Brasil, junto à ligação da Lagoa dos Patos com o mar, a cidade de Rio Grande/RS possui um legado histórico importante por sua localização geográfica estratégica. Grande parte do seu acervo arquitetônico encontra-se em acelerado estado de desgaste, frente às condições ambientais adversas. Este trabalho abordará alguns aspectos das principais manifestações patológicas associadas às envoltórias das edificações, baseadas nos sistemas construtivos das edificações do início do século XX, afetadas pelas grandes variações térmicas locais, lençol freático superficial e os fortes ventos além da presença de maresia. A principal contribuição deste trabalho está na identificação do desgaste causado por estes agentes climatológicos, associadas à falta de manutenção e conservação, causadores de severos danos ao patrimônio arquitetônico histórico edificado local. Assim, o trabalho abordará alguns aspectos comuns a estas edificações, representados pelo estudo de caso de uma residência construída em 1903. A partir de métodos avaliativos visuais, foram identificadas patologias importantes, comumente encontradas nas inspeções destes imóveis. Esperase que a posterior identificação de procedimentos para a correção dos problemas venha produzir um meio de consulta, auxiliar na manutenção dos exemplares ainda existentes, e de conscientização, salutar para a criação de políticas públicas e de incentivos econômicos para a sua preservação.

ABSTRACT: Located in the southern region of Brazil, near to the connection of the Patos Lagoon with the sea, the city of Rio Grande / RS has a historical legacy important because of its strategic location. Much of its architectonic environment finds itself in an accelerated state of wear, front to adverse environmental conditions. This work will address some aspects of the main diseases associated with wrappers of buildings, based on constructive systems of buildings from the early 20th century, affected by large thermal variations, site surface aquifer, the strong winds and the presence of salt. The main contribution of this work is the identification of wear Caused by These agents climatologic, linked to a lack of maintenance and conservation, Causing severe damage to historic architectural heritage site built. Thus, the work will address some issues common to These buildings, Represented by case study of a residence built in 1903. From viasual evaluation methods, Were identified significant pathologies, commonly found in inspections of These buildings. It is expected que the subsequent identification of procedures for the correction of problems will produce the means of consultation, assist in Maintaining the exemplars still exist, and awareness, and a salutary for the creation of public policies and economic incentives for Their preservation. 


\section{INTRODUÇÃO}

Este estudo representa um pequeno recorte da situação do patrimônio histórico nos municípios do interior do Rio Grande do Sul, onde a falta de legislação adequada, de políticas públicas responsáveis e de incentivo econômicos aos proprietários dos imóveis históricos, fazem com que as condições climatéricas e o desgaste natural do tempo, sejam aceleradores da decrepitude de seus exemplares histórico-arquitetônicos nestas cidades.

O patrimônio construído na cidade de Rio Grande/RS, bem como a arquitetura edificada a partir do final no final do século XIX possui um sistema construtivo de origem portuguesa, com características e técnicas similares em praticamente todo o litoral sul-brasileiro. O Inventário de Bens Culturais, do município, conta com uma relação de 509 imóveis que foram identificados como de interesse cultural. Destes, cerca de $50 \%$ estão localizados no bairro Centro, e cerca de metade destes fazem parte da coleção de imóveis edificados no início do século XX. As Figuras 1 e 2 mostram exemplares de arquitetura construídos no início do século $X X$, na região central da cidade, e que apresentam características edilícias similares, presentes na maioria dos exemplares que se encontram ainda edificados a cidade.

$\mathrm{Na}$ cidade em estudo, algumas particularidades caracterizam-na quanto a sua arquitetura, como a grande presença de casas térreas, em lotes com pouca testada, sem recuo de ajardinamento, com o uso de platibandas e, em alguns casos, a presença de para-ventos incorporados à construção. Outra característica peculiar é a existência de uma grande variação térmica e outros agentes atmosféricos importantes, como fortes ventos e maresia. Em função deste macro clima criado com a ação conjunta de variação térmica, fortes ventos e alta maresia muitas destas edificações citadas se encontram em estado avançado de deterioração, por abandono ou falta de conservação e/ou manutenção preventiva, apresentando várias manifestações patológicas que afetam o sistema construtivo e, em muitos casos, comprometem a sua estabilidade e futura permanência. A partir desta contextualização este levantamento intenta provocar a conscientização de que a manutenção destes bens é tarefa importante e inadiável, sob pena da comunidade perder os exemplares edilícios que contam a história local.

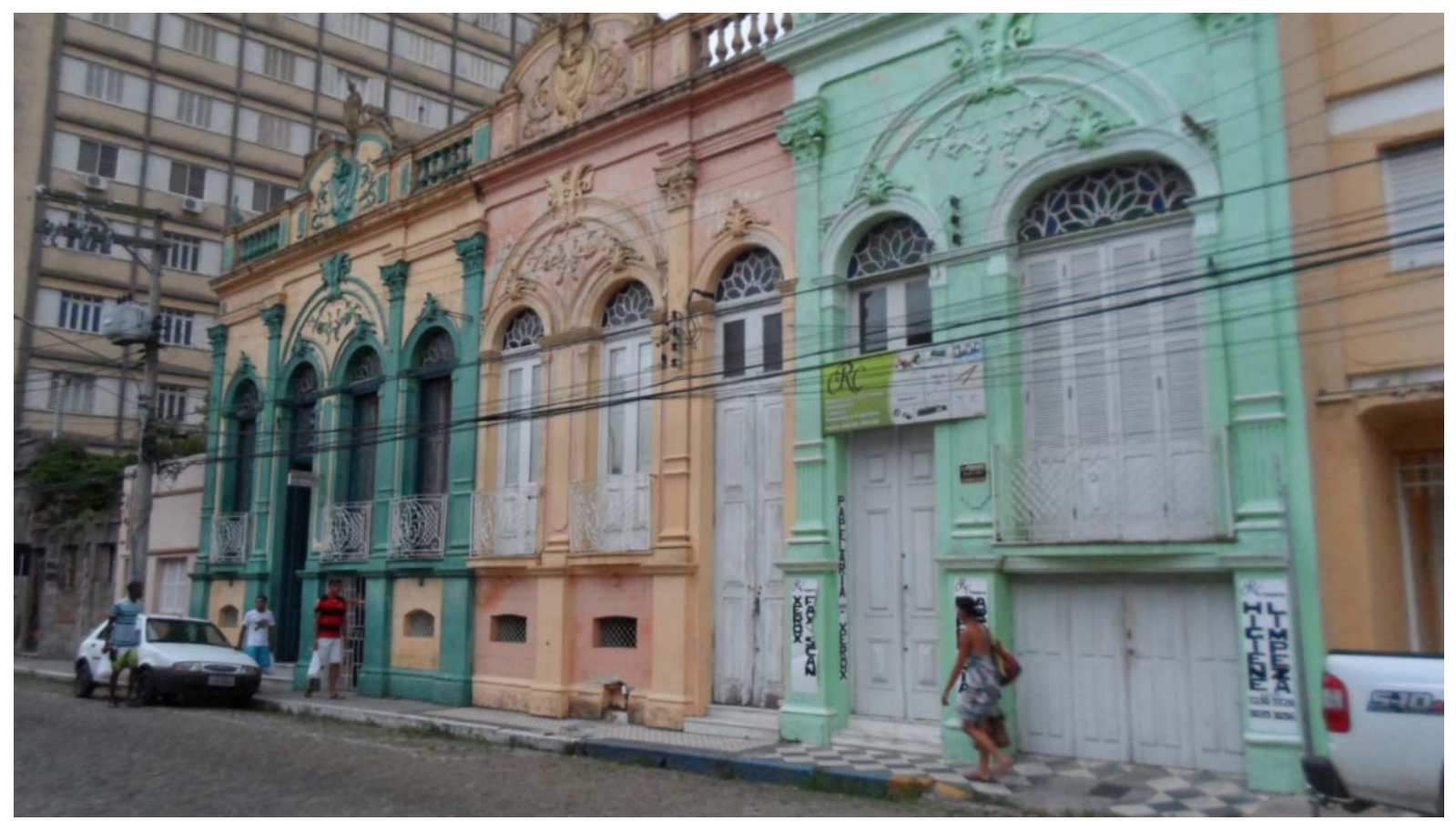

FIGURA 1: Conjunto arquitetônico construído entre 1906 e 1911 na Rua Gal. Bacelar, Rio Grande-RS. Fonte: Arquivos pessoais das autoras. 


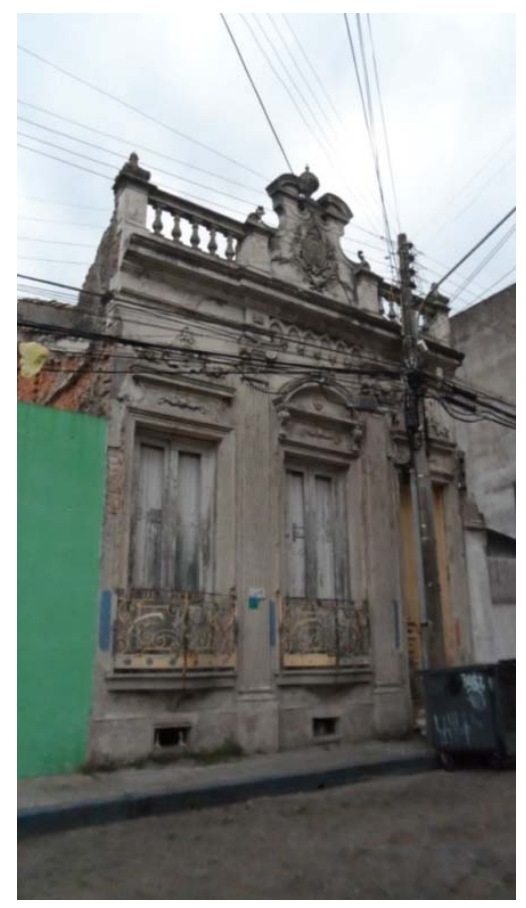

[a]

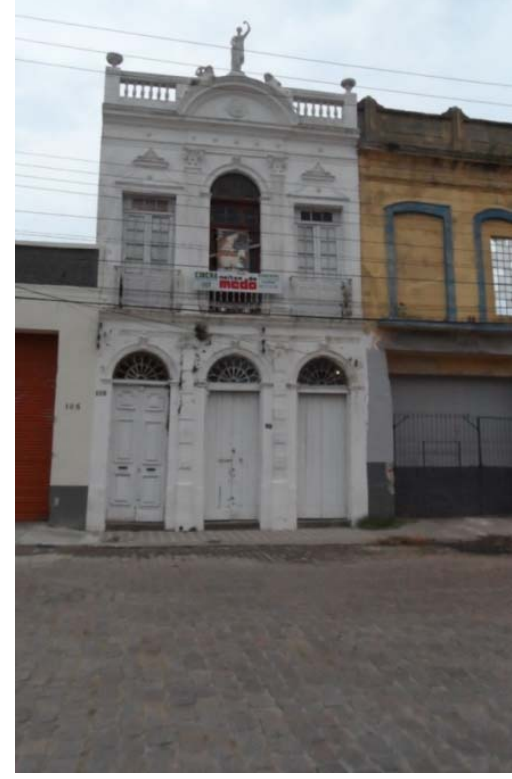

[b]

FIGURA 2: (a) Residência de 1908 na Rua Gal. Bacelar e (b) Rua Riachuelo, de 1906. Fonte: Arquivos pessoais das autoras.

\section{OBJETIVO}

O objetivo deste trabalho foi realizar um levantamento das principais manifestações patológicas identificadas nas construções realizadas no início do século XX, considerando suas técnicas construtivas, tipologias edilícias e materiais disponíveis na época de sua execução. Além de que concentrou a atenção nas manifestações patológicas associadas às condições climáticas da região e escolheu uma edificação para realizar o estudo de caso.

\section{MANIFESTAÇÕES PATOLOGICAS}

Patologia é um termo que surgiu na área médica para considerar o desvio em relação ao que é considerado normal (FERREIRA, 2015). Na área da engenharia este termo é utilizado para designar que a edificação ou seus componentes estão, por alguma razão, tendo um desempenho insatisfatório (CREMONINI, 1988). Assim, segundo o mesmo autor, faz-se necessário uma análise através de seus sintomas, suas origens e causas, mecanismos de ocorrência e consequências. Na prática, segundo Verçoza (1991), a patologia das construções é o estudo de situações de ocorrências de problemas, falhas ou defeitos que desequilibram a função para o qual o edifício foi criado. Para ele, o profissional que tem conhecimento desta ciência, reduz muito a chance de cometer erros já na fase de projeto. 0 autor menciona que esse conhecimento é tão importante quanto à responsabilidade profissional na execução da obra.

O estudo desta área ganhou importância em nível internacional na década de 60, primeiramente com elementos estruturais e posteriormente estendeu-se aos demais elementos construtivos (TERRA, 2001). No Brasil, já em 1980, IOSHIMOTO realizou um trabalho pesquisando a ocorrência de problemas patológicos em 36 conjuntos habitacionais (LICHTENSTEIN, 1986). No estado do Rio Grande do Sul, em 1988, DAL MOLIN realizou o primeiro estudo que quantificou os problemas patológicos ocorridos no referido estado, onde constatou que a maior incidência foi devido à fissuração. Já, no interior do estado do Rio Grande do Sul, Terra (2001) realizou um estudo das manifestações patológicas em revestimento de fachadas, encontrando como lesões mais frequentes: manchas de sujeira ou vegetação parasitária, fissuras, umidade e descolamentos.

Ao analisar o conceito de desempenho 
significa que a edificação, deve ter o seu comportamento em uso, ou seja, o desempenho de uma edificação está relacionado com ela cumprir sua função quando sujeita a certas ações, definindo as necessidades ou exigências dos usuários (PERES, 2001). As edificações antigas também devem possuir a capacidade de desempenho, porém sempre respeitando o seu valor histórico e cultural.

Para Arendt (1997), para recuperação de edificações antigas são utilizados os mesmos princípios de técnicas, da química e da física, como para os prédios novos. Porém com restrições de materiais, técnicas e detalhes, devido à incompatibilidade com os materiais e técnicas antigas. Segundo Peres (2001), tratando-se de obras históricas, leva-se em consideração mais um agravante, a manutenção do valor histórico da edificação, o que proporciona uma barreira às tentativas de manutenção destas edificações, quando se opta por resguardar o existente. Este procedimento resulta no agravamento das manifestações patológicas, em especial às ocasionadas por falta de manutenção.

Helene (1992) relata que no diagnóstico das manifestações patológicas, os problemas podem ser separados em dois tipos: os que afetam as condições de segurança da estrutura (mais urgentes); e os que comprometem somente as condições de higiene e estética, denominadas condições de serviço, associadas aos estados limites de utilização.

Uma edificação está constantemente submetida à ação de diversos agentes agressivos como calor, umidade, ação de ventos, sobrecargas, que irão, com o passar do tempo, produzir desgaste, obsolescência e sua fadiga, provocando o aparecimento de problemas em seus componentes construtivos.

As manifestações patológicas derivadas da umidade são muito constantes nas edificações. Elas podem se manifestar em diversos elementos construtivos - fachadas, pisos, paredes internas, forros, entre outros. As origens destes problemas podem estar relacionadas com deficiências de impermeabilização dos baldrames, porosidade dos revestimentos argamassados, percolação pelas telhas, defeitos, desgaste ou entupimentos em calhas e condutores pluviais, vazamentos de tubulações de água ou esgoto, problemas de projetos ou execução, entre outros, de forma isolada ou um conjunto de vários fatores apresentados. Assim, a presença de umidade é um meio para que várias incidências surjam na edificação (Verçoza, 1991), sendo fator essencial para o aparecimento de eflorescências, corrosões, deterioração de pinturas e de rebocos, aparecimento de fungos, descolamentos e fissuras, além da perda de capacidade estrutural de alvenarias e estruturas de concreto.

Nas construções antigas, a redução natural na resistência dos materiais empregados provoca a deterioração, agravada pela ação agressiva climática. De acordo com Helene (2003), os principais agentes de deterioração das edificações são: (1) fatores físicos (variações de temperatura, umidade, calor excessivo, raios ultravioletas, vento, chuva, maresia); (2) fatores químicos (poeira, fuligem, gases poluentes, maresia); (3) fatores biológicos (fungos, insetos, vegetação, bactérias, animais); (4) fatores antrópicos (manuseio, vandalismo, uso inadequado, transportes, processo construtivo inadequado); e (5) fatores naturais (cheias, incêndios, ventos, chuvas, tremores).

Rio Grande é uma cidade litorânea que possui como principais agentes de deterioração a maresia e o vento. As regiões litorâneas têm como fator agressivo sua atmosfera marinha, que carrega os sais (cloretos de sódio e de magnésio) suspensos no ar por grandes distâncias, depositando-os nos elementos construtivos sob a forma de partículas de água. Outro fator que colabora na incidência das manifestações patológicas é que a cidade situa-se à cerca de sete metros acima do nível do mar, associado a uma composição do solo arenoso com lençol freático superficial. A umidade, cerca de $85 \%$, é a origem mais frequente dos danos identificados nos prédios, em toda esta região (Peres, 2001), bem como no interior da edificação também. 


\section{METODOLOGIA}

Para a análise das manifestações patológicas, Lichtenstein em 1986 desenvolveu uma metodologia estruturada em três partes distintas: levantamento de subsídios, diagnóstico da situação e definição de conduta. Para o mesmo autor, os subsídios levantados são fundamentais para a formulação do diagnóstico e a definição da conduta. Lichtenstein (1986) explica que o registro de subsídios pode ser realizado manualmente através de croquis e/ou indicações nas plantas ou pode ser feito através de registros permanentes como fotografias e filmagens.

Já Prodanov e Freitas (2013), relatam que o método científico é um conjunto de procedimentos adotados com o propósito de atingir o conhecimento. Sendo a observação uma técnica de coleta de dados que permite conseguir informações e utilizar os sentidos na obtenção de determinados aspectos da realidade. Esse tipo de método busca observar os fatos ocorridos em determinado ambiente, conforme eles são percebidos, sem uma prévia preparação (MARCONI e LAKATOS, 2003).

A estratégia desta pesquisa foi o estudo de caso, pois, segundo Yin (2001), esta estratégia é utilizada quando o pesquisador tem pouco controle sobre os eventos e quando o foco se encontra em fenômenos contemporâneos inseridos em algum contexto da vida real.
O estudo foi realizado através de um levantamento visual e fotográfico das manifestações patológicas encontradas nas fachadas da edificação em questão, para posterior análise das causas e origens das anomalias. O ambiente da pesquisa foi a edificação, construída em 1903, localizada na Rua Cel. Bacelar (Figura 3) no Centro da cidade de Rio Grande/RS. Atualmente o imóvel encontra-se desocupado e está à venda. Assim, tem sofrido muita degradação pela umidade e falta de ventilação, visto que permanece fechado.

A parte principal da edificação é composta por um bloco frontal de um pavimento, construído no alinhamento, sem recuo frontal, com fachada composta por uma porta e duas janelas, assim como um portão que dá acesso ao pátio lateral. A planta da casa é distribuída ao longo de $150 \mathrm{~m}^{2}$ e têm uma tipologia de corredor lateral e uma sequência de dormitórios e salas, todos ligados ao corredor principal, tendo alguns compartimentos ligados entre si. A casa possui, no bloco posterior, a sala de jantar, um dormitório, uma cozinha, uma área de serviço e um banheiro, este situado bem ao fundo do lote. $O$ assoalho é composto de madeira, tipo tábua corrida nos dormitórios e salas. O forro em toda casa, exceto área da cozinha, serviços e banheiro, é de madeira do tipo saia e camisa pintado com tinta esmalte. No hall de entrada e corredor, o piso de ladrilhos hidráulicos decorados, bem as paredes com

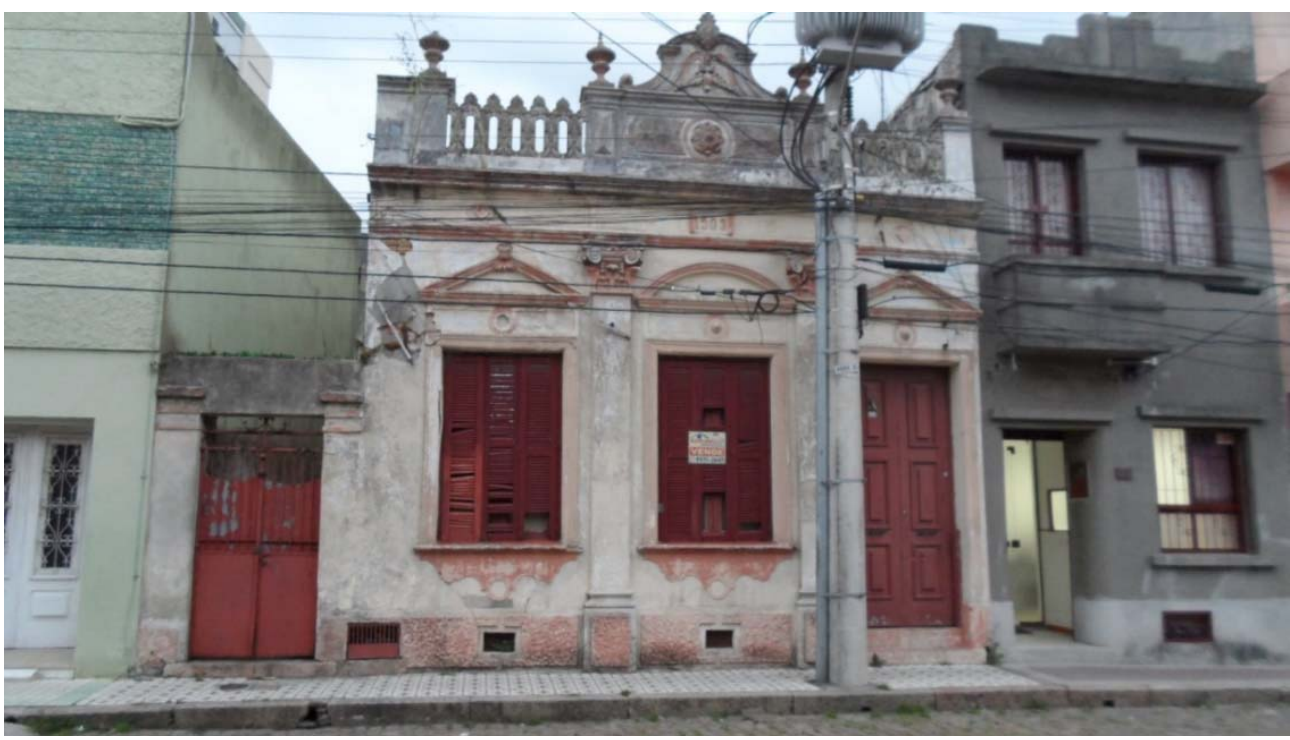

FIGURA 3: Foto da fachada da Rua Cel. Bacelar - Rio Grande/RS, edificada em 1903. Fonte: arquivos pessoais das autoras. 
escaiola imitando mármore, demonstram a preocupação com um acabamento diferenciado. A cobertura original em telha de barro do tipo capae-canal sobre estrutura de madeira, foi parcialmente substituída por telha de fibrocimento $6 \mathrm{~mm}$. Embora o prédio não esteja em bom estado de conservação, ainda mantém a maioria dos elementos arquitetônicos característicos da época em que foi construído.

A implantação, apresentada na Figura 4 mostra os dois blocos ligados pelo corredor. A presença do pátio lateral permite uma insolação e ventilação maior nos compartimentos.

O sistema construtivo é composto por paredes estruturais em tijolo argamassado com areia e cal, com cerca de $40 \mathrm{~cm}$ de espessura. As fundações são em alvenaria de pedra e cal. As paredes divisórias internas são confeccionadas em alvenaria de tijolos com cerca de $20 \mathrm{~cm}$ de espessura. Os revestimentos do edifício são, basicamente, executados em reboco de areia e cal com pintura, tanto interna como externamente.

Os vãos da edificação são compostos por janelas e portas, ambas com duas folhas. As portas externas são em pranchas de madeiras macheadas, sendo que a porta principal é almofadada. A porta do para-vento tem bandeiras com vedação em vidro. As portas internas, também em pranchas de madeira têm as bandeiras superiores em vidro com caixilho tipo basculante, permitindo a iluminação e a ventilação entre os ambientes. As janelas de madeira, tem caixilhos de vidro do tipo de abrir para o exterior, possuem tampões internos.

O clima de Rio Grande é subtropical ou temperado, com forte influência oceânica e presença de invernos relativamente frios, verões quentes e precipitações regularmente distribuídas durante o ano. A temperatura média anual da cidade é de $18,3^{\circ} \mathrm{C}$. Janeiro é o mês mais quente, com temperatura média de $23,6{ }^{\circ} \mathrm{C}$, alcançando $38,6^{\circ} \mathrm{C}$, e julho é o mês mais frio, com temperatura média de $12,9^{\circ} \mathrm{C}$ chegando a $2{ }^{\circ} \mathrm{C}$. Devido à intensa incidência de ventos na cidade, a sensação térmica na estação do inverno em Rio Grande frequentemente chega abaixo de $0{ }^{\circ} \mathrm{C}$.

\section{LEVANTAMENTO VISUAL}

A investigação de uma estrutura requer uma abordagem interdisciplinar que ultrapassa simples considerações técnicas, reunindo também a investigação histórica, que nos fornece informações sobre as técnicas construtivas e comportamentos estruturais (ICOMOS, 2004), processo de degradação e danos.

Este estudo se limitou a analisar os dados qualitativos através da análise pela inspeção visual da construção, fazendo um mapeamento dos danos visíveis, com o objetivo de identificar as principais degradações e os efeitos do meio ambiente sobre a edificação.

O imóvel, referente ao estudo de caso, está relacionado pela Prefeitura Municipal no Inventário de Bens Culturais e faz parte do Inventário do Patrimônio Cultural do Estado IPHAN.

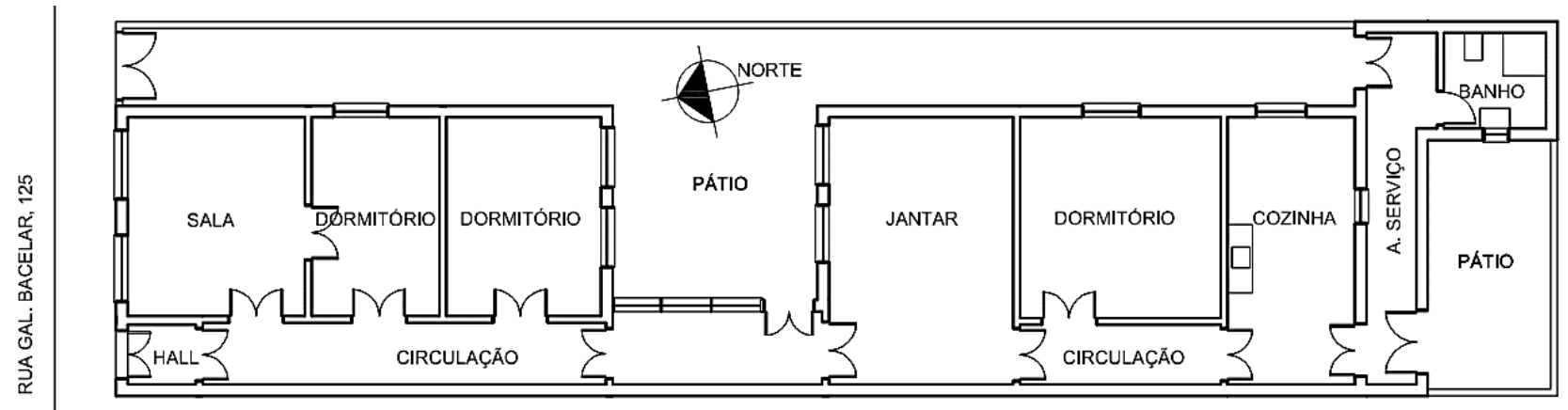

FIGURA 4: Planta baixa da Rua Cel. Bacelar - Rio Grande/RS.

Fonte: Arquivos pessoais das autoras. 
Como não foi localizado o projeto original da residência, foi produzida uma planta baixa esquemática, respeitando as dimensões existentes. Os desenhos, produzidos em AutoCAD 2000, serão apresentados na forma de figura, ao longo do trabalho, sem escala. Eles indicarão, em planta, a localização das manifestações patológicas. As fotos de todos os pontos foram feitas registrando os pontos visíveis da degradação, a Figura 5 apresenta o levantamento geral do estudo de caso, onde foram identificadas as seguintes manifestações patológicas: descolamentos, fissuras, sujicidades, degradação de esquadrias, umidades ascendentes e descendentes.

\subsection{DESCOLAMENTOS}

O descolamento de revestimentos está na literatura apresentado de uma forma mais ampla, abarcando toda a gama de despreendimentos da superfície revestida, desde cerâmicas, até pinturas em geral, resultando em pouca especificidade. Aqui, neste trabalho, foi associado apenas 0 descolamento de rebocos de argamassa. A origem desta manifestação patológica pode ser atribuída desde o emprego de materiais inadequados, passando pelo erro de projeto ou execução, até a falta de manutenção, sendo este último o responsável pelo maior número de casos. Os descolamentos podem surgir por problemas de umidades, fissuras, presença de vegetação ou microrganismos. Nestes casos, o descolamento geralmente é pontual.

Analisando a Figura 6, visualizamos a localização dos descolamentos do revestimento de argamassa na fachada.

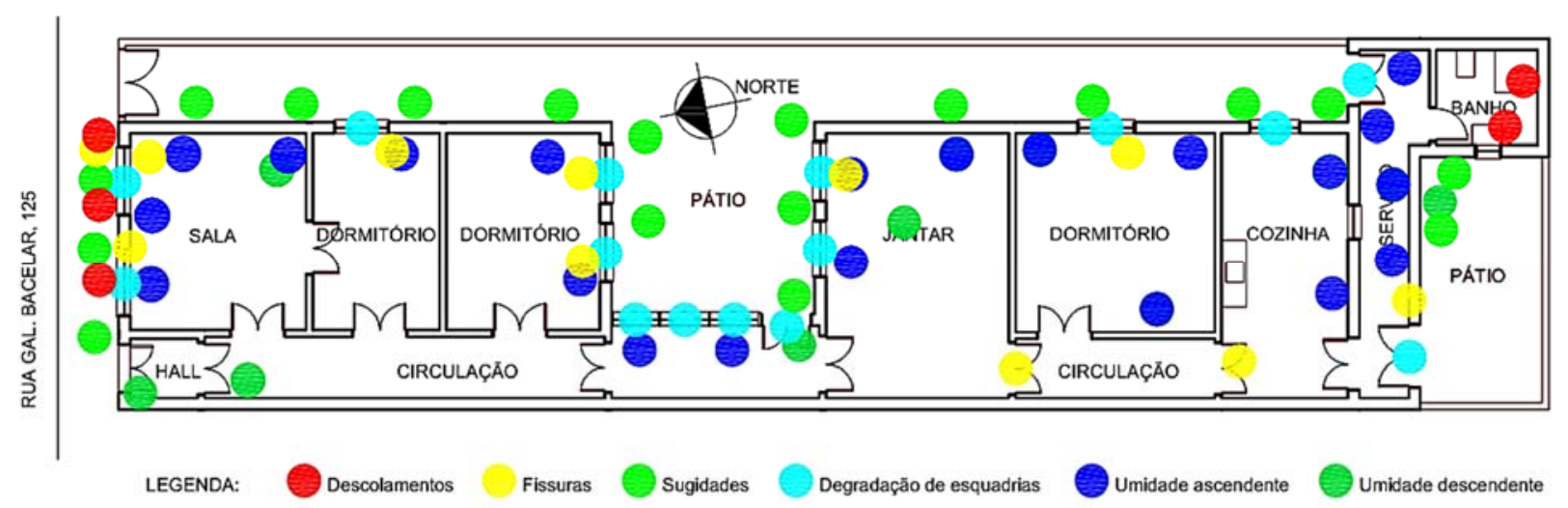

FIGURA 5: Planta geral de localização das manifestações patológicas.

Fonte: Arquivos pessoais das autoras.

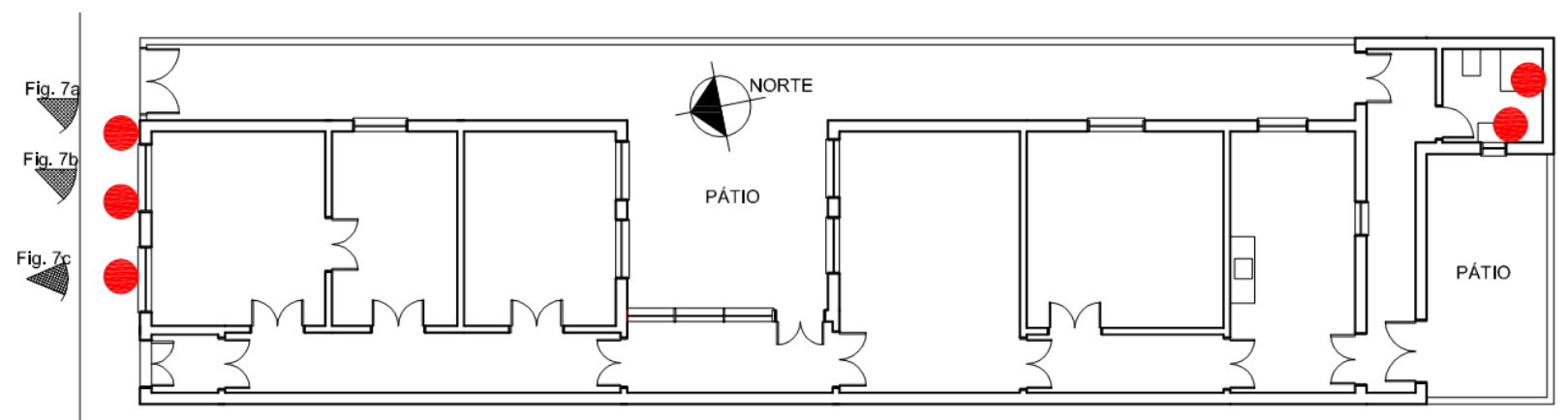

FIGURA 6: Planta de localização dos descolamentos.

Fonte: Arquivos pessoais das autoras. 
As argamassas tradicionais são permeáveis, permitindo a passagem de água para o seu substrato. Quando isto é aliado à execução manual, sujeita aos aspectos físicos e ambientais, o risco de ocorrer uma variabilidade das características e de comportamento sob o ponto de vista da permeabilidade do reboco é grande.

Conforme levantamento e análise efetuada no local, o problema do descolamento do revestimento na fachada principal (Figura 7) pode ter ocorrido por infiltração derivada do constante transbordamento da calha ou condutor pluvial (existe marca de umidade nas paredes internas que indicam este problema) localizado no encontro de duas águas do telhado na parte posterior da platibanda frontal ou, ainda, pela trinca na platibanda, devido à falta da cinta de amarração na face superior e capeamento da platibanda. A umidade constante nessa face da parede provocou o descolamento tanto do reboco da parede como dos adornos que acompanham as janelas frontais.

\subsection{FISSURAS}

As fissuras são pequenas aberturas que podem surgir nas estruturas, revestimentos ou no substrato de uma edificação. Podem ter origem em recalques do solo, retração de revestimentos, movimentação ou acomodação da estrutura, falta de amarração nas paredes ou ainda, por fatores diversos como diferenças térmicas ou de esforços. Aqui neste ponto percebe-se que um dano pode gerar outros, ou seja, a existência de uma fissura facilita a penetração de água (CARVALHO, 2014). Observando as Figuras 8 e 9 nota-se a presença de vários pontos de fissuras. Possivelmente este aparecimento foi motivado pela inexistência de viga de amarração superior ou verga nas portas e janelas, diferença térmica no comportamento entre alvenarias e aberturas.

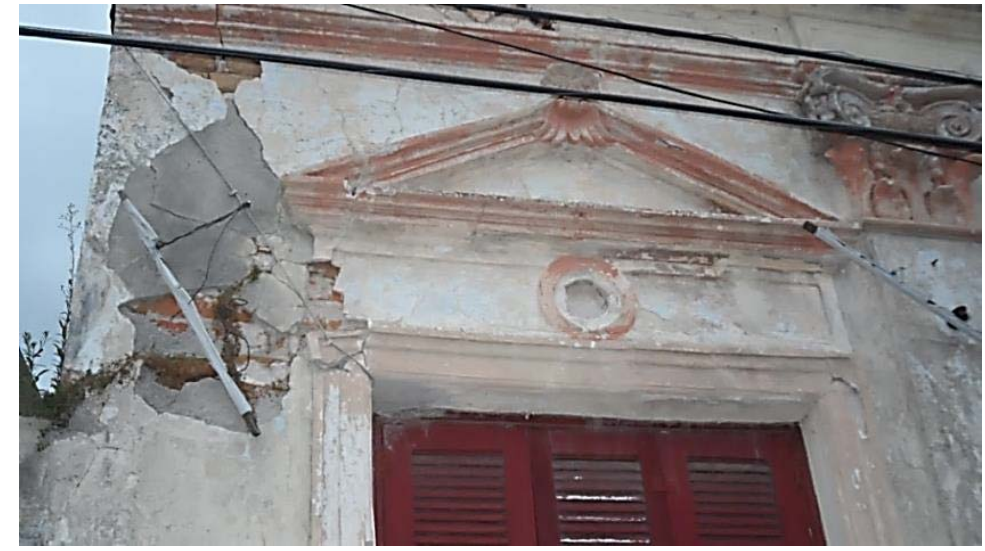

[a]

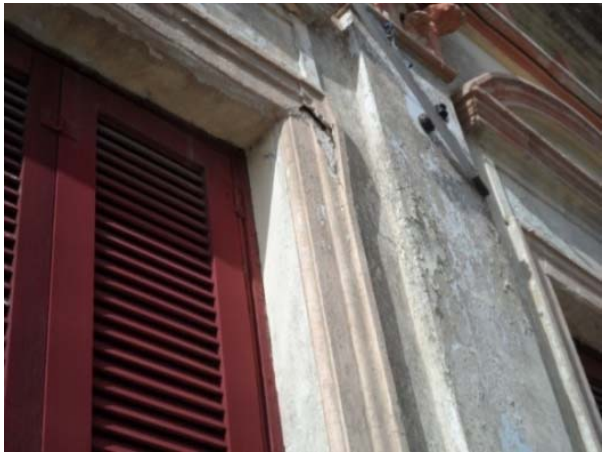

[b]

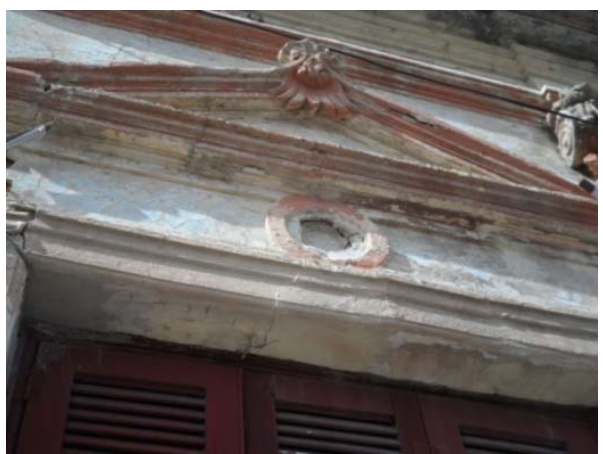

[c]

FIGURA 7: Descolamentos do reboco da fachada frontal devido: (a) à infiltração decorrente de fissura na platibanda e transbordamento da calha e condutor pluvial; (b) à fissura ocorrida pela ausência da verga da janela; (c) à fissura gerada com o comprometimento (corrosão ou apodrecimento do elemento estrutural) da verga da janela.

Fonte: Arquivos pessoais das autoras. 


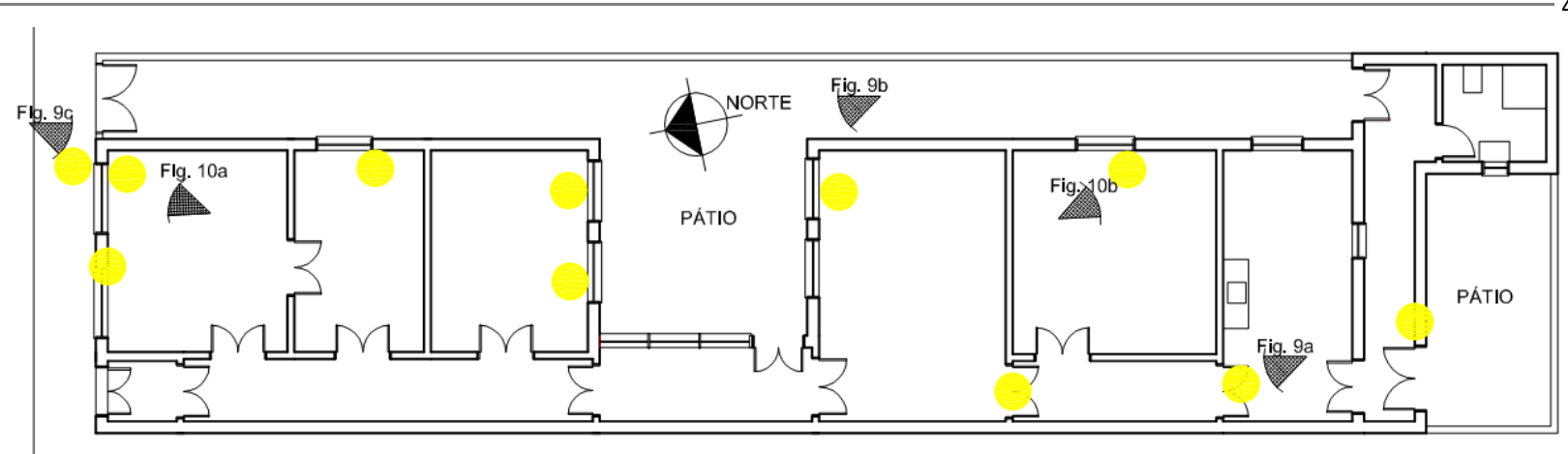

FIGURA 8: Planta de localização das fissuras Fonte: Arquivos pessoais das autoras.

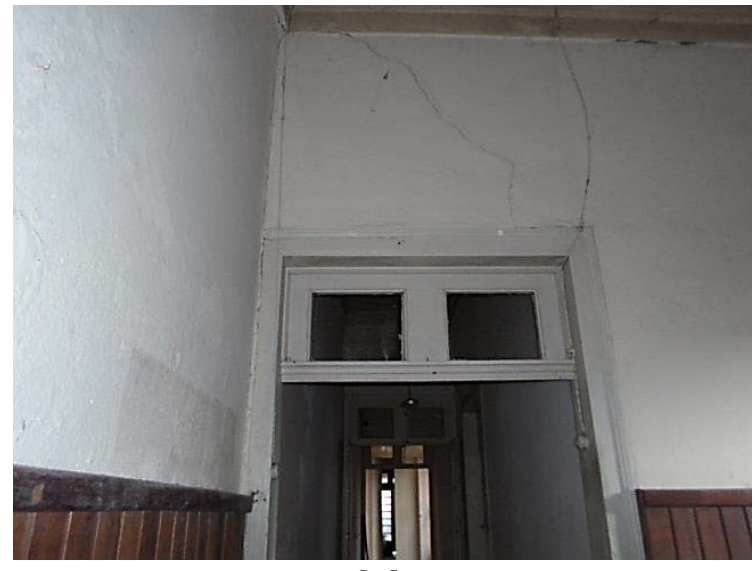

[a]

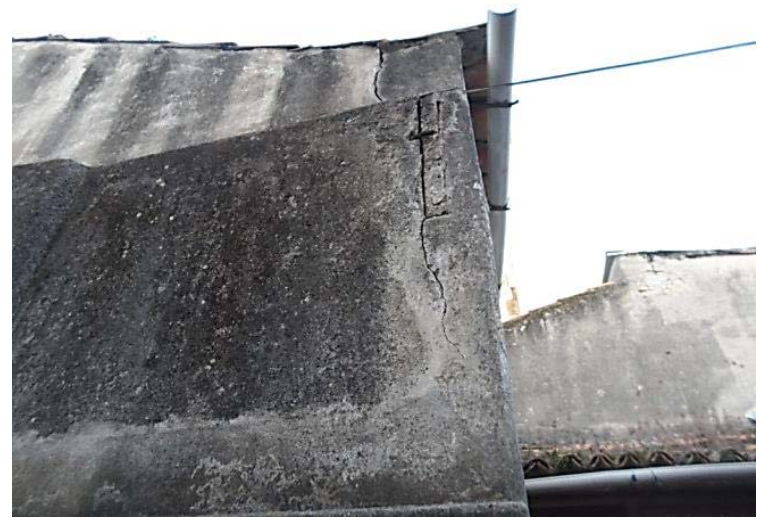

[b]

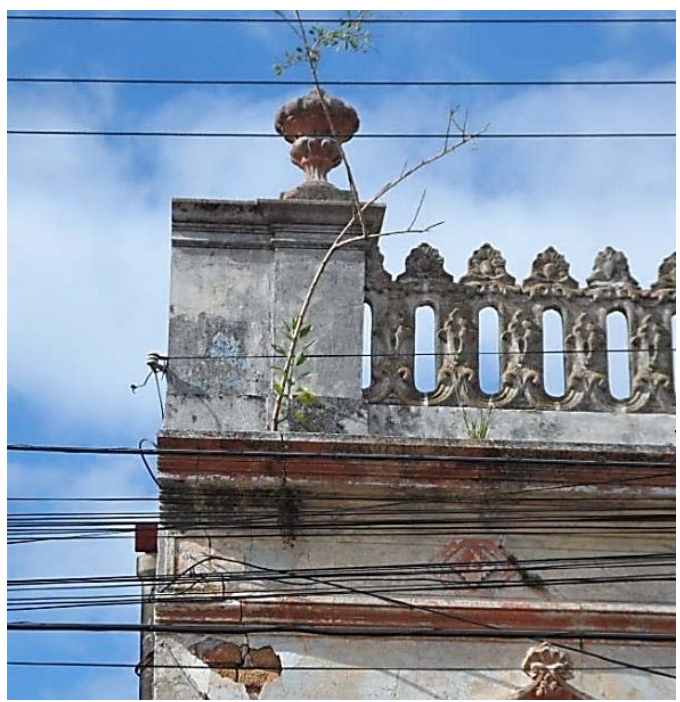

[c]

FIGURA 9: Fissuras Internas e externas: (a) fissuras em cima de uma porta interna da residência; (b) fissura na platibanda externa do telhado; (c) fissura originada pela presença de vegetação no telhado na fachada principal da casa.

Fonte: arquivos pessoais das autoras.

A fissuração (Figura 10) contribui para a diminuição da durabilidade das construções, uma vez que, além de demonstrar a manifestação de um problema, favorece o aparecimento de outras anomalias. Assim, na zona fissurada dá-se uma perda de estanqueidade do elemento afetado, permitindo a penetração de água e a ocorrência de degradação por ação de sais, carbonatação ou ciclos de variação térmica intensa.

A fissura do material é normalmente produzida pelo esforço de tração que provoca tensões superiores à capacidade resistente do 


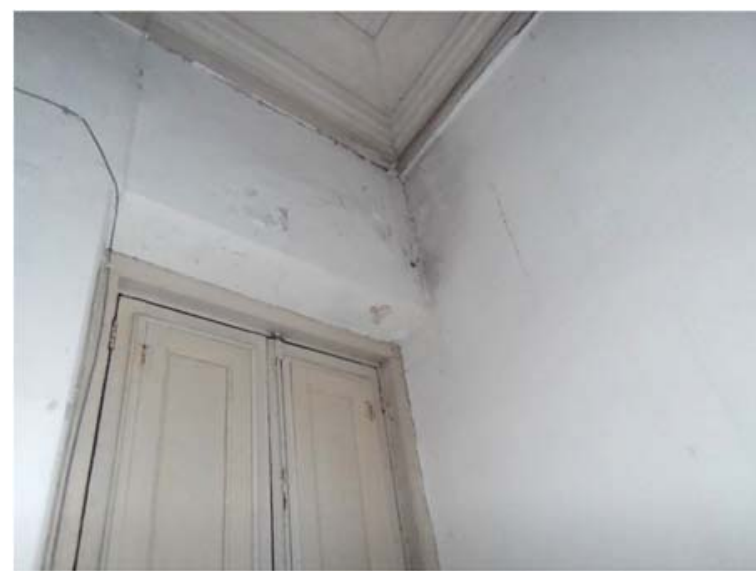

[a]

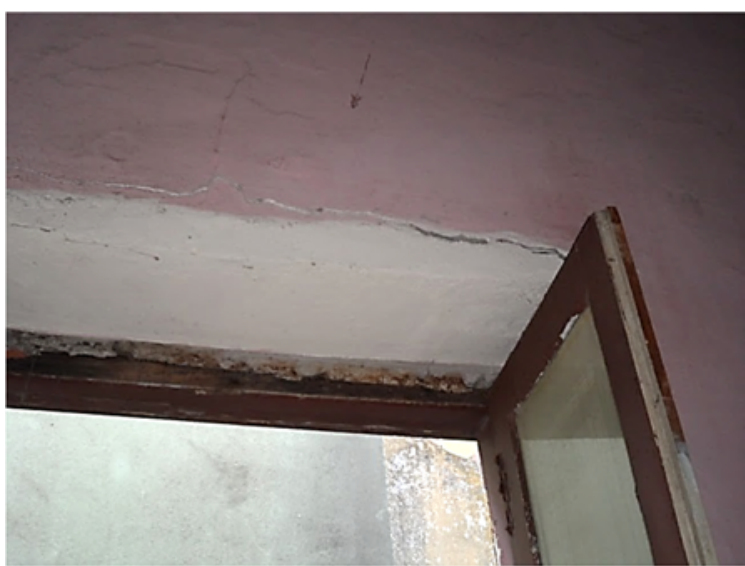

[b]

FIGURA 10: Fissuras nos cantos das janelas: (a) fissuras localizadas em cima de uma janela; (b) fissuras localizadas em cima de uma janela. Fonte: Arquivos pessoais das autoras.

material, ou seja, quando as variações dimensionais ultrapassam capacidade de resistência dos elementos, estes fraturam, criando uma descontinuidade/fissura. Estas fissuras localizam-se em pontos de menor resistência, normalmente ao nível das vergas dos vãos, que são zonas de menor inércia.

As causas podem ser por diferenças nas deformações higrotérmicas (tração e retração causada por ação da temperatura adicionada à umidade) da alvenaria com um desenvolvimento normalmente horizontal, nas zonas onde as tensões são mais elevadas. As dilatações e contrações geradas por variações de temperatura, principalmente em fachadas norte e oeste, no hemisfério sul.

\subsection{SUJIDADES DE ORIGEM BIOLÓGICA}

A sujidade das fachadas (Figuras 11 e 12) é decorrência do acumulo de partículas nas superfícies das fachadas. Podem, na maioria das vezes, ser removidos com simples limpeza. Mas, a adesão das partículas ao revestimento pode ocorrer de cinco diferentes maneiras: força da gravidade, união química, forças moleculares, forças elétricas e tensão superficial (CHAVES, 2009). Para agravar o quadro, geralmente os ornamentos argamassados existentes na fachada antigas, são potenciais elementos para acúmulo de água e sujidade, provocando patologias.

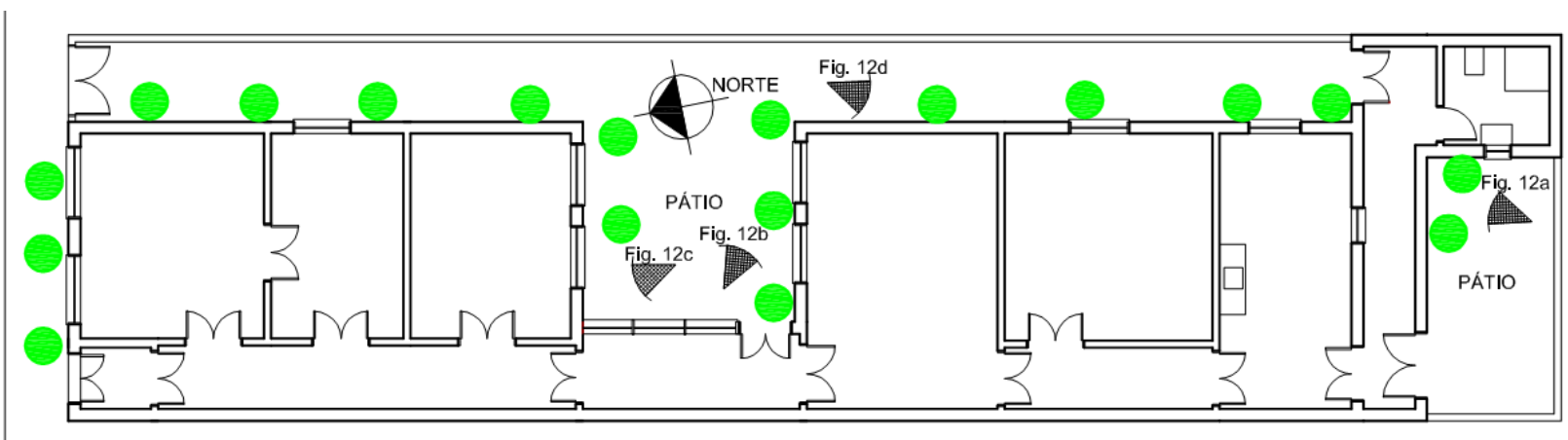

FIGURA 11: Planta de localização das sujidades.

Fonte: arquivos pessoais das autoras. 


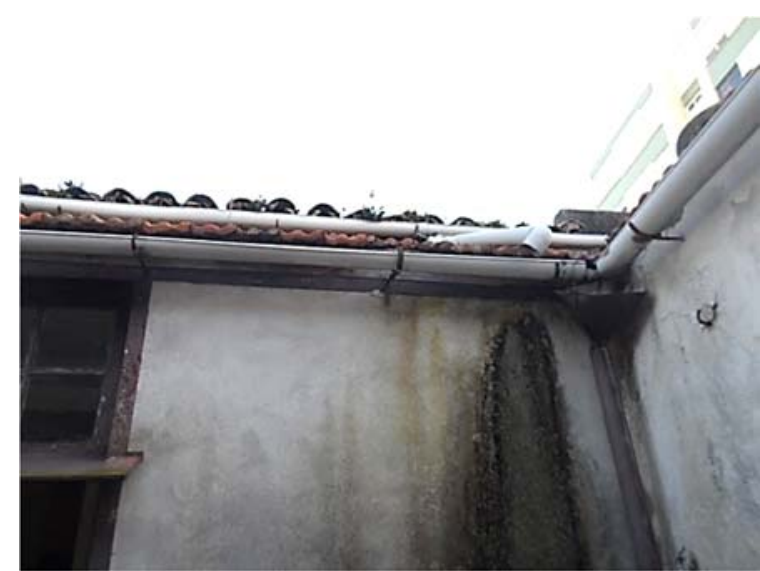

[a]

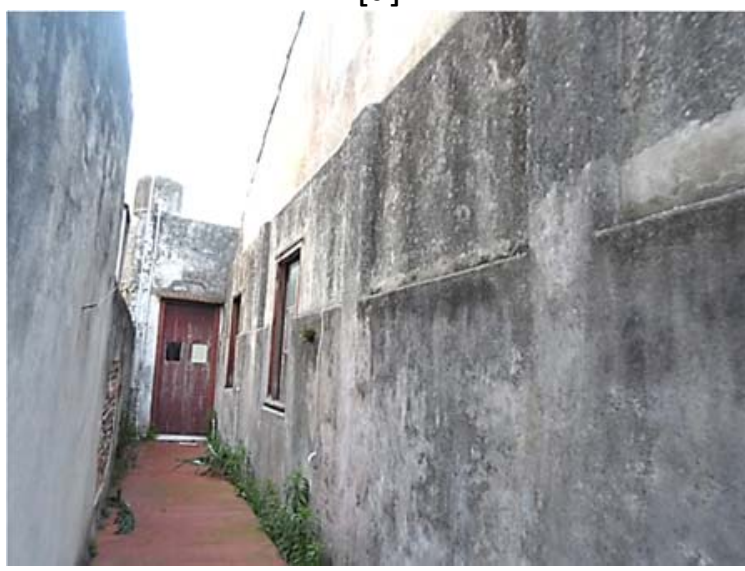

[c]

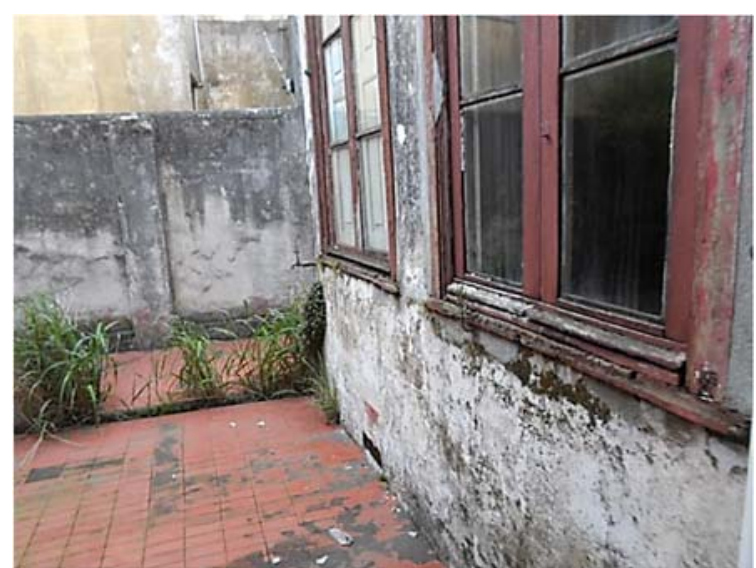

[b]

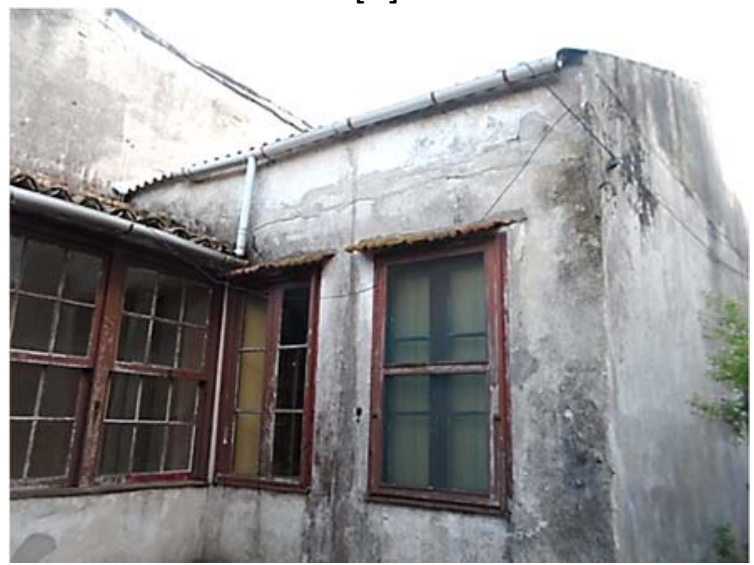

[d]

FIGURA 12 - Sujidades e deterioração das pinturas externas: (a) sujidade com origem de colapso da calha; (b) sujidade abaixo das janelas; (c) sujidade nos muros de acesso lateral da casa, local sem incidência solar; (d) sujidade ao redor das esquadrias. Fonte: arquivos pessoais das autoras.

\subsection{DETERIORAÇÕES DAS ESQUADRIAS}

Observando as Figura 13 e 14 identificamos que a infiltração das paredes e suas fissuras, a falta de limpeza e ventilação constante dos elementos móveis das janelas e portas, bem como a exposição contínua à umidade, provoca o apodrecimento das madeiras.

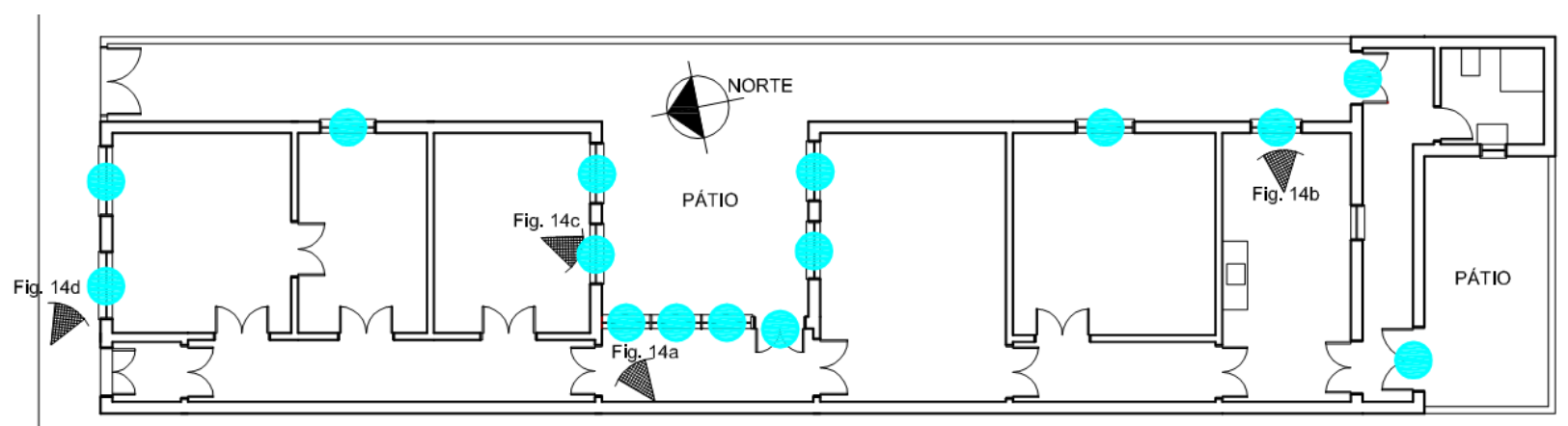

FIGURA 13: Planta de localização das DETERIORAÇÕES DAS ESQUADRIAS

FONTE: arquivos pessoais das autoras. 


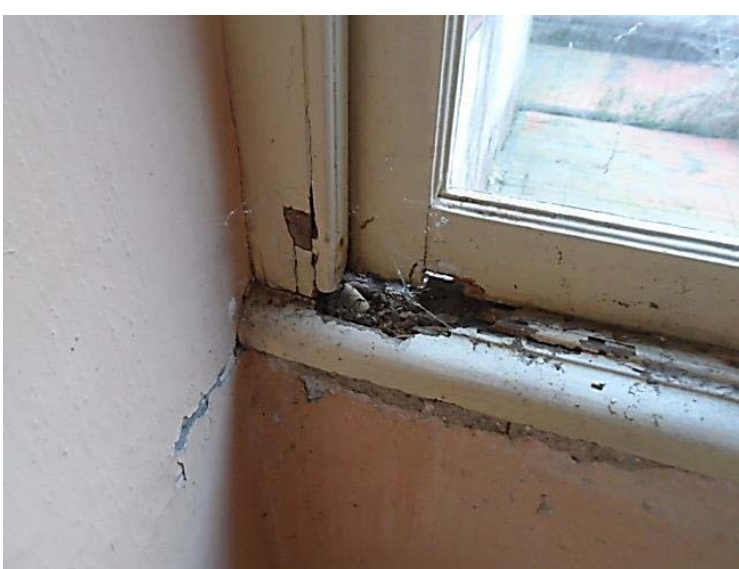

[a]

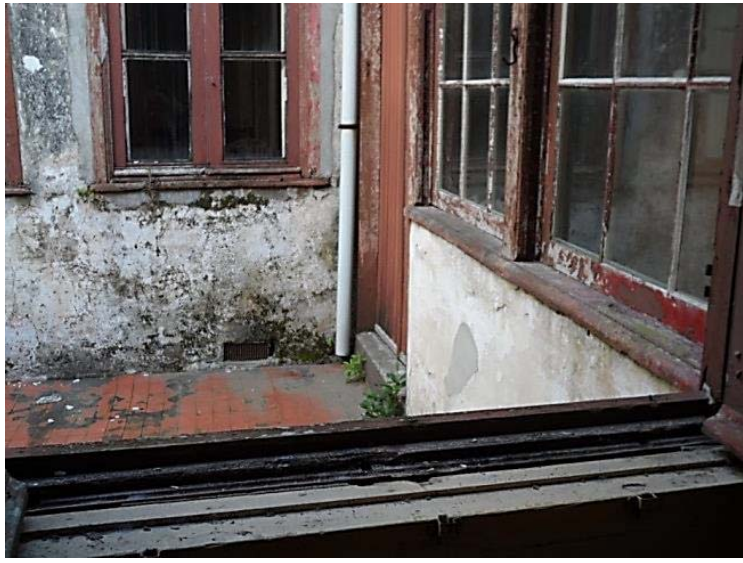

[c]

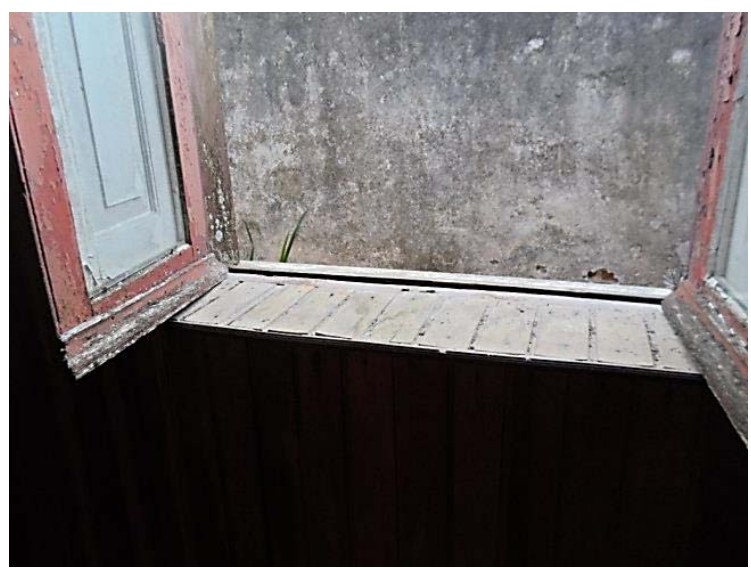

[b]

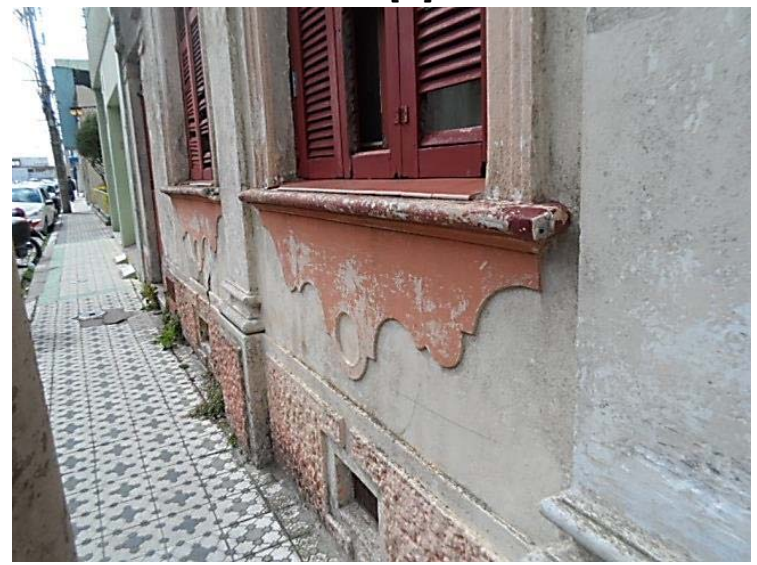

[d]

FIGURA 14: Deterioração das esquadrias: (a) vista interna da madeira de esquadria em processo avançado de degradação; (b) vista externa da madeira de esquadria em processo avançado de degradação; (c) vista geral das esquadrias em avançado processo de deterioração; (d) outra vista geral das esquadrias em avançado processo de deterioração.

Fonte: Arquivos pessoais das autoras.

\subsection{UMIDADE ASCENDENTE}

A presença de umidade ascendente (Figuras 15 e 16) nos imóveis da cidade de Rio Grande é muito comum. Este problema é ocasionado pela capilaridade da umidade presente no solo devido à falha ou à falta de impermeabilização adequada no alicerce ou viga de fundação. Isto pode ser provocado também pela destruição da camada impermeabilizante devido à presença de muita salinidade no ar e na água. Além de como já foi citado, a cidade está acima do nível do mar, ocasionando a proximidade do lençol freático das fundações das edificações.

Esta patologia, além de influir negativamente na habitabilidade dos ambientes, provoca um aspecto estético desagradável, pois além das manchas e pulverulências, promove um cheiro de mofo, devido aos fungos particulados no ar, promovendo alergias e doenças.

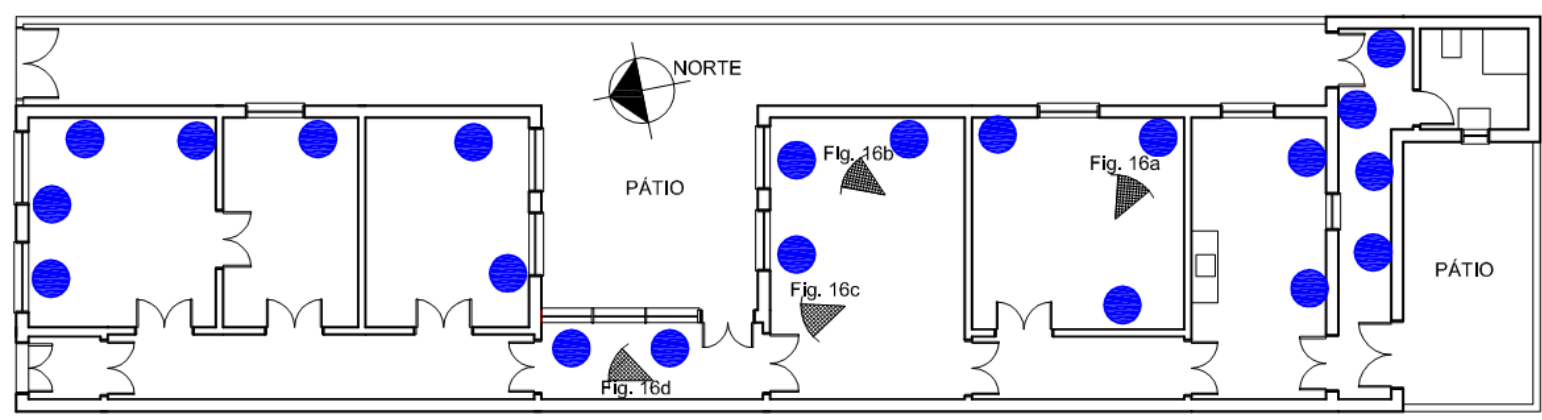

FIGURA 15: Planta de localização da Umidade Ascendente Fonte: Arquivos pessoais das autoras. 


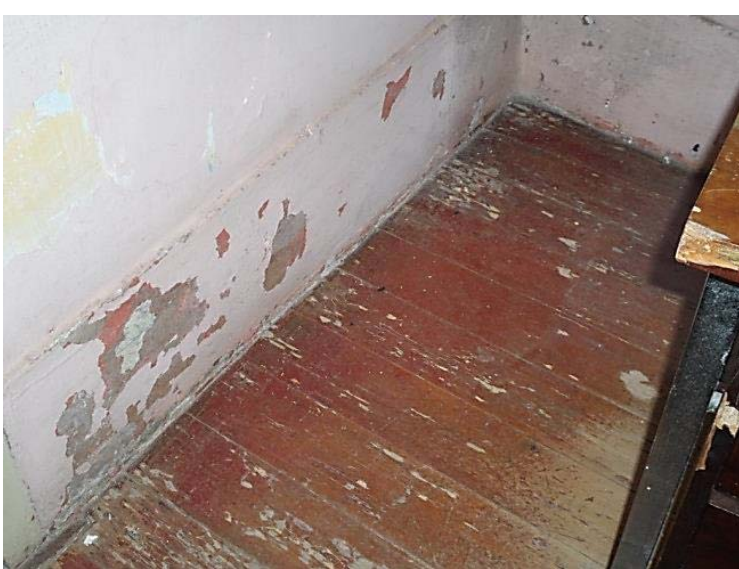

[a]

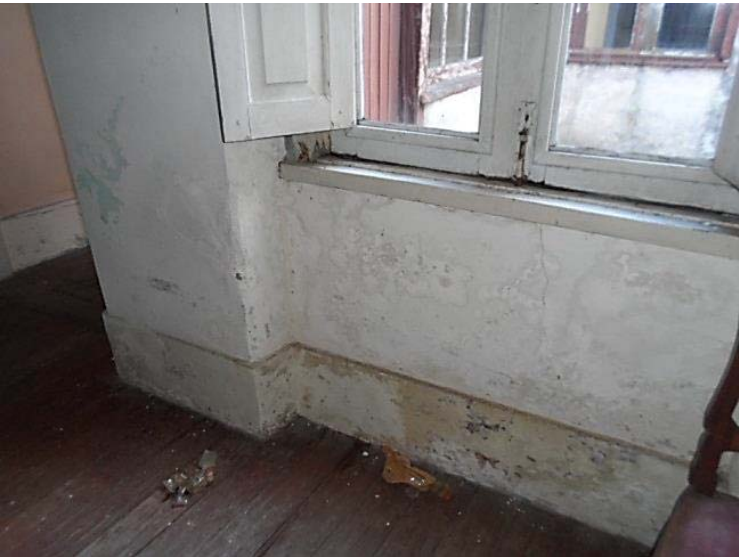

[c]

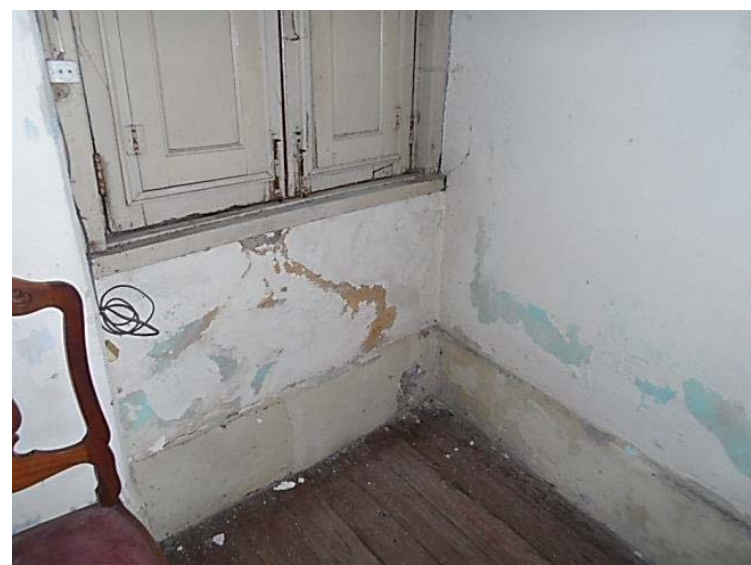

[b]

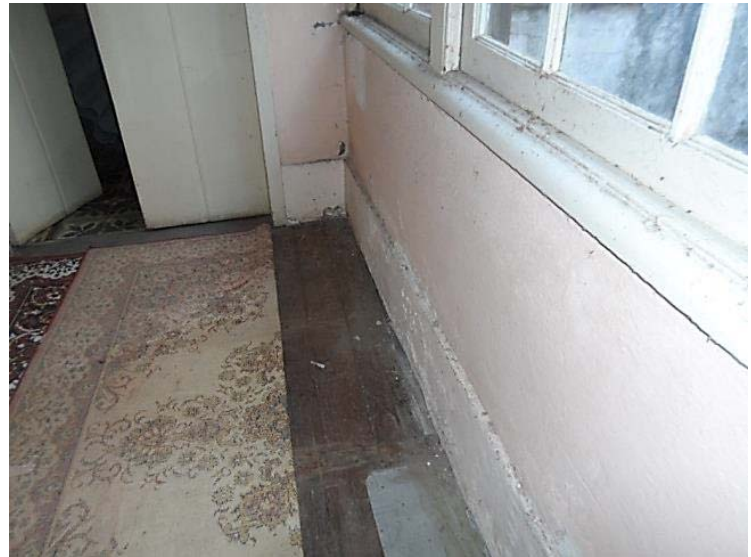

[d]

FIGURA 16: Umidade ascendente: (a) umidade próximo ao piso; (b) processo de umidade por capilaridade abaixo da janela; (c) outra esquadria da casa com umidade ascendente; (d) parede e piso da residência com umidade ascendente.

Fonte: Arquivos pessoais das autoras.

\subsection{UMIDADE DESCENDENTE}

A consequência derivada da umidade descendente é outra peculiaridade destas edificações. Como é comum o uso de platibandas para esconder o telhado, é também muito frequente $o$ aparecimento deste tipo de manifestação patológica, ora derivado do envelhecimento das telhas (percolação, fissuras e deslocamentos), ora pela deterioração da estrutura do telhado (apodrecimento ou ataque de cupins) ou ainda pela deficiência no sistema de calhas e condutores pluviais. Na Figura 17 identificamos os pontos que apresentam problemas deste gênero e na Figura 18 as fotos dos estragos já provocados na residência, como o apodrecimento do forro e do assoalho de madeira, o desnivelamento do telhado, demonstrando que há problemas com sua estrutura de madeira, deslocamento de calhas e condutores.

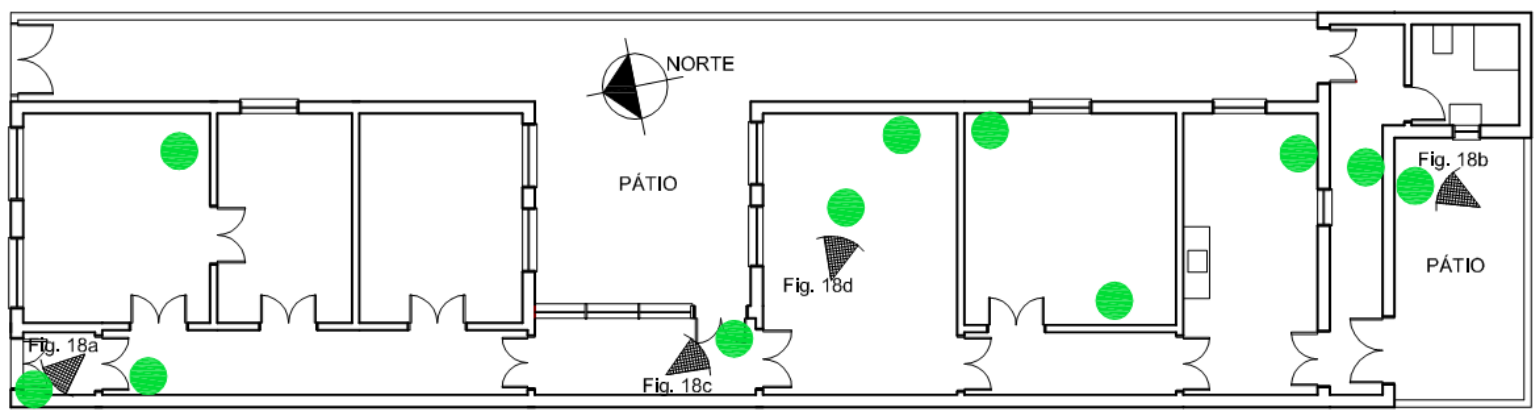

FIGURA 17: Planta de localização da Umidade Descendente Fonte: Arquivos pessoais das autoras. 


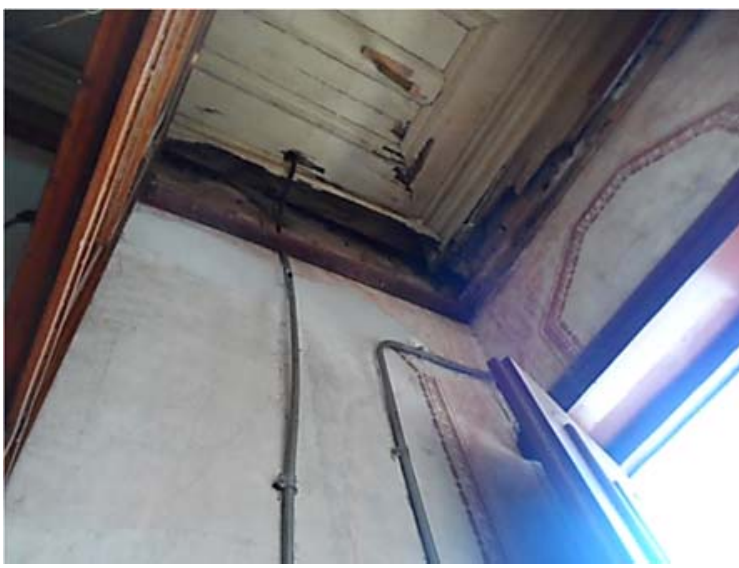

[a]

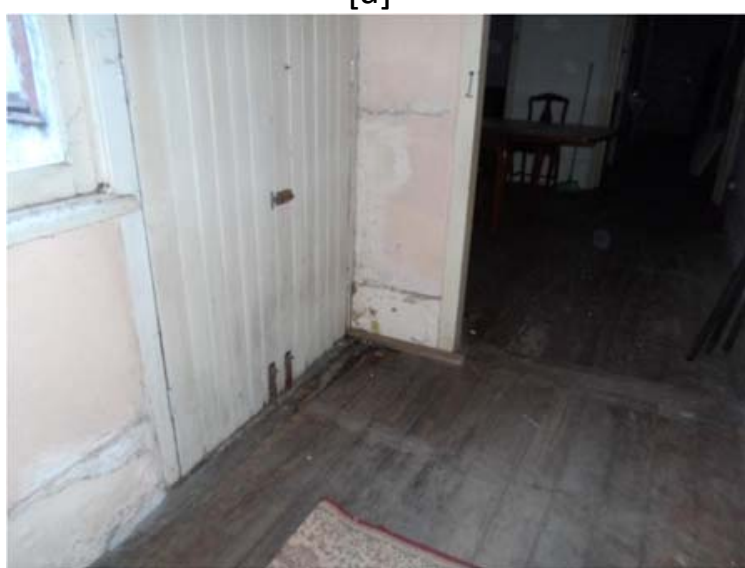

[c]

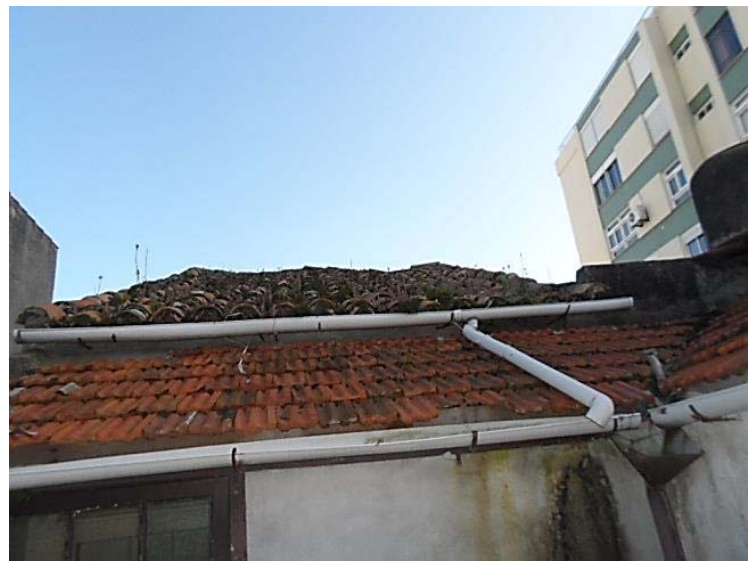

[b]

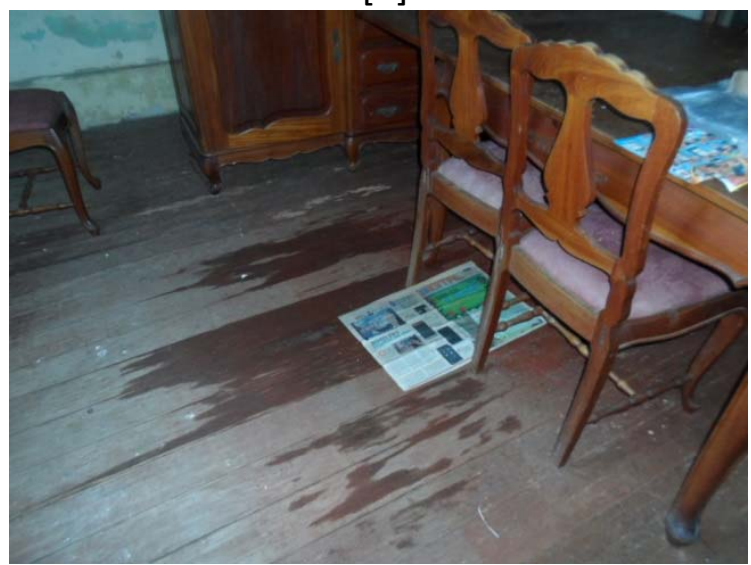

[d]

FIGURA 18: Infiltração descendente causada por deficiências no telhado, calhas e condutores: (a) forro de madeira com avançado processo de degradação pela umidade; (b) imagem do telhado da residência com problemas; (c) ação da água nas paredes, por ausência de telhado; (d) piso com água em função de falta de telhado.

Fonte: Arquivos pessoais das autoras.

\section{DISCUSSÃO DOS RESULTADOS}

A principal causa de deterioração das edificações históricas está diretamente condicionada ao envelhecimento inevitável dos materiais construtivos, agravada pelas condições ambientais e climáticas a que são expostos esses bens materiais ao longo do tempo. No item anterior foram apresentadas todas as manifestações patológicas que foram identificadas nesta residência, demonstrando que a falta de manutenção provoca uma degeneração generalizada e crescente, principalmente nas áreas que estão em contato com o lado exterior, os panos de fechamento e as vedações.

Os maiores danos foram verificados devido à falta de manutenção. Os problemas de infiltração pelo telhado, pelas calhas e condutores, pela falta de pintura nas paredes e nas esquadrias, apodrecimento de madeiras pelo contato com a umidade, todos são derivados de falta de cuidados de manutenção, gerando uma decadência dos materiais e a aceleração de sua decomposição ou descolamento.

A Tabela 1 apresenta as sugestões de intervenções nestas manifestações patológicas encontradas na edificação em estudo a fim de auxiliar para solução dos problemas. 
TABELA 1: Manifestação patológica x solução.

Verificar a condição da calha e condutor pluvial e efetuar os reparos e substituições; Remover o revestimento existente;

Descolamentos

Reparar a zona contígua à entrada de água pluvial de modo a impedir entrada de umidade;

Recuperar as vergas das janelas e fissuras das platibandas;

Recuperar o substrato, removendo todas as partículas soltas e microrganismos;

Aplicar novo revestimento.

Remover o revestimento não aderente ao longo da fissura, a vegetação e resíduos biológicos;

Fissuras

Executar a abertura da junta em forma de $\mathrm{V}$ ao longo de toda a fissura, com largura superior

a $150 \mathrm{~mm}$ e efetuar selagem da fenda com mastique de poliuretano;

Aplicar argamassa de reparação com uso de tela e após a secagem, este material receberá novo revestimento em argamassa e pintura.

Colocação de pingadeiras nos peitoris e extremidades superiores das paredes (platibandas) para o correto encaminhamento das águas;

Proceder a limpeza do local através da aplicação de uma solução à base de água limpa e

Sujidade sabão;

Realizar uma limpeza mecânica com escovas para a remoção da camada de tinta solta, os microrganismos, poeira, resíduos de poluição, sais, etc.;

Retirar a camada de tinta não removida durante o processo de lavagem com raspagem;

Aplicar um primer ou selador e posteriormente tinta, conforme especificações do fabricante.

Trocar as partes que foram afetadas pela deterioração;

Trocar os vidros quebrados e as massas de vedação dos vidros;

Deteriorações das esquadrias

Isolar com mastiques as esquadrias, junto às alvenarias e instalar pingadeiras, quando for possível.

Realizar pintura com stein ou tinta esmalte de boa qualidade para proteger os caixilhos.

Remover os revestimentos atacados pelo problema de umidade;

Efetuar limpeza para remover as partículas que podem influir na aderência da nova impermeabilização escolhida;

Realizar novo processo impermeabilizante no substrato inferior destas paredes, avaliando qual a melhor alternativa para cada caso. Pode ser através da aplicação de substâncias cristalizantes, ou com propriedades bloqueadoras de umidade, ou ainda, de forma mais radical, com a remoção alternada de trechos inferiores da parede de alvenaria, possibilitando nova impermeabilização do baldrame e posterior fechamento da alvenaria;

Refazer os revestimentos das paredes, aguardar a secagem completa da parede; Efetuar nova pintura.

Revisar a estrutura de madeira, refazendo os lotes de estrutura avariados pela umidade ou ataque de cupins, substituindo as peças estragadas;

Umidade descendente
Fazer a limpeza das peças de telhas e troca daquelas que apresentarem avarias e fissuras; Impermeabilizar as telhas utilizando produto específico para este fim; Instalar manta impermeável acima da madeira e abaixo das telhas;

Trocar calhas, rufos, algerosas e condutores pluviais;

Efetuar manutenções periódicas, visando acúmulos de lixo e folhas que provocam entupimentos ou transbordamentos de calhas e condutores pluviais.

\section{CONCLUSÕES}

O levantamento feito das principais manifestações patológicas provocadas pela ação do clima especificamente para as construções históricas do início do século XX, identificando suas técnicas construtivas e tipologias edilícias mais comuns, deteve sua atenção para as patologias associadas com planos verticais das construções, bem como suas coberturas.

Estima-se que os custos de recuperação de um bem imóvel é muitas vezes maiores do que os custos envolvidos com a sua manutenção e reparos frequentes. $E$ as ações de manutenção corretiva, sem critério técnico, podem acumular 
uma sucessão de erros e onerar ainda mais o custo de manutenção de uma edificação histórico cultural. Os revestimentos comprometidos geram uma perda na qualidade de uso do bem e o aumento de custo na manutenção, resultando em patologias por uso inadequado e não por falha de construção (CARVALHO, 2011).

A importância da manutenção destes bens para o patrimônio da comunidade deverá ser acompanhada de políticas públicas que incentivem seus proprietários na busca por apoio, com incentivos fiscais, linhas de crédito mais acessíveis e campanhas de valorização do patrimônio existente do município. Esta recuperação favorece a desenvolvimento cultural local, o turismo e fortalece a cultura local. Este levantamento intentou provocar a conscientização de que a manutenção destes bens é tarefa importante e inadiável, sob pena de a comunidade perder os exemplares edilícios que ainda contam a história local.

Ocorre que estes bens, geralmente são herdados de família, onde já existem outros interesses envolvidos, e a atenção ao bem é geralmente relegada ao último lugar nas prioridades, ora por falta de recursos financeiros, ora por ignorância dos valores que envolvem um bem histórico cultural.

As ações corretivas propostas nos casos apresentados acima, podem ser aplicados em outros casos semelhantes, significando um ganho com a recuperação das manifestações patológicas de forma adequada, cessando assim, processos de degradação que se aceleram com o passar do tempo. Além disto, este trabalho vibra pela criação de políticas públicas e leis de responsabilização mais eficientes provocariam talvez uma mudança de paradigma com relação ao bem cultural de propriedade privada.

\section{REFERÊNCIAS BIBLIOGRÁFICAS}

ARENDT, Claus. O Exaustivo Caminho da Recuperação. In: Congresso Ibero Americano de Patologia das Construções, 4, 1997, Porto Alegre: CPGEC/UFRGS, 1997.
CARVALHO, Isabella Chaves; PICANÇO, Marcelo de Souza; MACEDO, Alcebíades Negrão. Identificação de patologias em fachadas e metodologia de análise: estudos de casos na Universidade Federal do Pará (D.O.I. 10.5216/reec.V9i2.29559). REEC - Revista Eletrônica de Engenharia Civil, [S.I.], v. 9, n. 2, out. 2014. ISSN 2179-0612. Disponível em: <http://www.revistas.ufg.br/index.php/reec/article/vie w/29559/17192>. Acesso em: 13 Ago. 2015. doi:10.5216/reec.v9i2.29559.

CHAVES, Ana Margarida Vaz Alves. Patologia e Reabilitação de Revestimentos de Fachadas Dissertação de Mestrado, Escola de Engenharia, Universidade do Minho, Portugal, 2009.

CREMONINI, R. A. Incidência de Manifestações Patológicas em unidades escolares na região de Porto Alegre: Recomendações para projeto, execução e manutenção. Dissertação (Mestrado em Engenharia Civil) - Universidade Federal do Rio Grande do Sul. Porto Alegre, 1988.

DAL MOLIN, D. C. C. Fissuras em estruturas de concreto armado: análise das manifestações típicas e levantamento de casos ocorridos no estado do Rio Grande do Sul. Porto Alegre-RS, 1988. 196 p. Dissertação (Mestrado). Universidade Federal do Rio Grande do Sul.

HELENE, P.R.L. Manual para reparo, reforço e proteção de estruturas de concreto. 2.ed. São Paulo: Pini, 1992.

HELENE, Paulo R.L. Manual de reparo, proteção e reforço de estruturas de concreto. São Paulo: Pini, 2003

ICOMOS - International Council on Monuments and Sites. Recomendações para a análise, conservação e restauro estrutural do patrimônio arquitetônico. Universidade do Minho. Departamento de Engenharia Civil, 2004. Disponível em <http://repositorium.sdum.uminho.pt/bitstream/1822 /3172/1/Recomendacoes_ICOMOS.pdf>. Acesso em: 15 Ago. 2015

IOSHIMOTO, E. Incidências de manifestações patológicas em edificações habitacionais. In: TECNOLOGIA DE EDIFICAÇÕES. Coletânea... São Paulo: Pini/IPT, 1988, p.545-548.

LICHTENSTEIN, N. B. Patologia das construções. Boletim técnico n. 06. SãoPaulo: USP, 1986.

LICHTENSTEIN, Norberto. Patologia das construções: procedimento para formulação de diagnósticos de falhas e definição de conduta adequada à recuperação de edificações. Dissertação de mestrado, Escola Politécnica, São Paulo, 1985, 191 p. 
MARCONI, M. de A.; LAKATOS, E. M. Fundamentos de Metodologia Científica. 5. ed. São Paulo: Atlas, 2003.

PERES, Rosilena Martins. Levantamento e identificação de manifestações patológicas em Prédio Histórico - um estudo de caso. Dissertação de mestrado, Programa em Pós-graduação em Engenharia Civil, UFRGS, Porto Alegre, 2001.

PRODANOV, C. C.; FREITAS C. E. Metodologia do Trabalho Científico: Métodos e Técnicas da Pesquisa e do Trabalho Acadêmico. 2a $\underline{\text { a }}$. Novo Hamburgo: Feevale, 2013. E-book.

TERRA, R. C. Levantamento de manifestações patológicas em revestimentos de fachadas das edificações da cidade de Pelotas. Dissertação do Programa de Pós-Graduação em Engenharia Civil Universidade Federal do Rio Grande do Sul, Porto Alegre, 2001.

VERÇOZA, Ênio José. Patologia das Edificações. Editora Sagra, Porto Alegre, 1991, 176 p.

YIN, R. K. Estudo de Caso: Planejamento e Métodos. 2. ed. Porto Alegre: Bookman, 2001. 